Bull. Chem. Soc. Ethiop. 2020, 34(3), 471-478.

ISSN 1011-3924

(c) 2020 Chemical Society of Ethiopia and The Authors

Printed in Ethiopia

DOI: https://dx.doi.org/10.4314/bcse.v34i3.4

\title{
SYNTHESIS, CHARACTERIZATION AND ANTIMICROBIAL ACTIVITIES OF HETEROLEPTIC METAL CHELATES OF ISONIAZID AND 2,2'-BIPYRIDINE
}

Olawale Folorunso Akinyele*, Emmanuel Gabriel Fakola, Lateefah Moyosore Durosinmi, Temitope Adekunle Ajayeoba and Ayowole Olaolu Ayeni

Department of Chemistry, Obafemi Awolowo University, Ile-Ife Nigeria

(Received March 10, 2019; Revised December 8, 2020; Accepted December 15, 2020)

\begin{abstract}
The $\mathrm{Mn}(\mathrm{II}), \mathrm{Co}(\mathrm{II}), \mathrm{Ni}(\mathrm{II}), \mathrm{Cu}(\mathrm{II})$ and $\mathrm{Zn}(\mathrm{II})$ complexes of isoniazid $\left(\mathrm{L}_{1}\right)$ mixed with 2,2bipyridine $\left(\mathrm{L}_{2}\right)$ were synthesized and characterized by solubility studies, percentage metal analysis, UV-Vis spectroscopy, IR spectroscopy, conductivity measurements and magnetic moment measurements. The IR spectra revealed that the isoniazid coordinated as a bidentate ligand. In $\mathrm{Co}$ (II) and $\mathrm{Ni}$ (II) complex it coordinated via the carbonyl oxygen $(\mathrm{C}=\mathrm{O})$ and the amide nitrogen, while in the $\mathrm{Cu}(\mathrm{II}), \mathrm{Mn}(\mathrm{II})$ and $\mathrm{Zn}(\mathrm{II})$ complexes it coordinated using the amide and carbonyl oxygen via enolization. Bipyridine also bonded to the metals as a bidentate ligand through the pyridinic nitrogen atoms. The magnetic data showed that all the complexes were paramagnetic with values ranging from 1.70 to 5.0 B.M., except $\left[\mathrm{Zn}(\mathrm{Is})(\mathrm{Bipy})\left(\mathrm{H}_{2} \mathrm{O}\right) \mathrm{Cl}_{2}\right]$ which was diamagnetic. The conductivity results revealed that the $\mathrm{Cu}(\mathrm{II}), \mathrm{Mn}(\mathrm{II}), \mathrm{Zn}$ (II) complexes were 1:1 electrolytes while $\mathrm{Co}(\mathrm{II})$ was 1:2 electrolyte and $\left[\mathrm{Ni}(\mathrm{Is})(\mathrm{Bipy}) \mathrm{Cl}_{2}\right]$ was non-electrolytic in nature. The antibacterial activities of the ligands and the complexes as evaluated via the agar diffusion method showed that the complexes displayed moderately high antimicrobial activity in comparison with the free ligands when tested against ten strains of bacteria.
\end{abstract}

KEY WORDS: Isoniazid, Electronic structure, Geometry, Antimicrobial activity, Electrolytic nature, Magnetic moment

\section{INTRODUCTION}

Isoniazid also known as isonicotino-hydrazide is a widely known drug used in the treatment of tuberculosis. It is always administered in combination with other drugs such as ethambutol, and pyrazinamide. Isoniazid acts as an antituberculosis drug by inhibiting the production of mycolic acid [1]. Apart from its use in the treatment of tuberculosis, it is recommended as a prophylaxis therapy for HIV patients having a PPD reaction of $5 \mathrm{~mm}$ [2]. Due to its ability to form hydrazones with ketones, it is used in chromatography to show distinctions between the various degrees of conjugation in organic compounds that possess a ketone group [3].

Isoniazid has been widely reported to form metal complexes that are relatively stable [4-6]. Interestingly some of these complexes have been reported to exhibit significant activity against several stains of $M$. tuberculosis including the resistant strains [6-8].

Reports on the studies of the complexes of isoniazid have shown that $\mathrm{Fe}(\mathrm{II})$ and $\mathrm{Cu}$ (II) complexes of isoniazid possess significant potential for the treatment of tuberculosis than the drug [9]. The synthesized complexes of isoniazid have been characterized and reported to posses both octahedral and tetrahedral geometries $[10,11]$. The synthesis and characterization of the mixed ligand complexes of isoniazid have been carried out [12], and their antimicrobial activity has been reported [13]. The studies have shown that the mixed ligand complexes had more activity on the micro-organisms than the free ligand.

However, reports on the synthesis, characterization and antibacterial activity of the Co(II), $\mathrm{Ni}(\mathrm{II}), \mathrm{Cu}(\mathrm{II})$, and $\mathrm{Zn}(\mathrm{II}), \mathrm{Mn}(\mathrm{II})$ mixed ligand complexes of isoniazid with 2,2-bipyridine has not been reported, the results of this study are herein reported.

*Corresponding author. E-mail: ofakinyele@oauife.edu.ng; ofakins@yahoo.com This work is licensed under the Creative Commons Attribution 4.0 International License 


\section{EXPERIMENTAL}

Reagents and solvents

All the chemicals and solvents (isoniazid, 2,2-bipyridine, methanol, copper(II) chloride dihydrate, manganese(II) chloride tetrahydrate, cobalt(II) chloride hexahydrate, and nickel(II) chloride hexahydrate) used in the study were obtained from Bond Pharmaceutical and BDH and used without further purification. The percentage metal content was determined by complexometric titration using EDTA and atomic absorption spectroscopy (AAS). The infrared spectra were recorded in the $4000-400 \mathrm{~cm}^{-1}$ region with a Shimadzu FT-IR 8000 spectrophotometer using $\mathrm{KBr}$ pellets. UV-Visible spectra of the samples were measured in the range $800-200 \mathrm{~nm}$ using a Shimadzu UV-Vis 1800 spectrophotometer. Magnetic susceptibility measurements were carried out at room temperature using a Sherwood Scientific MXI model Gouy magnetic balance. Melting points of the compounds were determined using a Gallenkamp melting point apparatus.

\section{Synthesis of mixed ligand complexes}

Solutions of each of the metal salts $\left(1 \mathrm{mmol}\right.$ of $\mathrm{CoCl}_{2} \cdot 6 \mathrm{H}_{2} \mathrm{O}, \mathrm{CuCl}_{2} \cdot 2 \mathrm{H}_{2} \mathrm{O}, \mathrm{MnCl}_{2} \cdot 4 \mathrm{H}_{2} \mathrm{O}, \mathrm{ZnCl}_{2}$, $\mathrm{NiCl}_{2} \cdot 6 \mathrm{H}_{2} \mathrm{O}$ ) in $5 \mathrm{~mL}$ of methanol was added into stirring homogenous solution of isoniazid (1 $\mathrm{mmol}$ ) and 2,2'-bipyridine (1 mmol) in $10 \mathrm{~mL}$ methanol. The solution was stirred for one hour at room temperature, during which precipitate was formed. The product was filtered, washed with methanol and dried over anhydrous calcium chloride.

\section{Antimicrobial study}

The biological activities of the synthesized ligands and their metal complexes have been studied for their antimicrobial activities. These microorganisms include typed cultures of National Collection of Industrial Bacteria (NCIB) and locally isolated organism (LIO). The bacterial strains were: Gram positive: Bacillus cereus, Staphylococcus aureus, Proteus vulgaris, Vibrofuminisi, Clostridium sporogenes. The Gram negative bacteria include, Escherichia coli, Pseudomonas aeruginosa, Pseudomonas flourescens, Klebsiella pneumoniae, Microccus luteus. Nutrient broth (biomark) and nutrient agar (rapid lab) were used for sub-culturing the organisms while Mueller-Hinton agar (LAB M) was used for sensitivity testing. The media were sterilized using autoclave at $121{ }^{\circ} \mathrm{C}$ and $1.05 \mathrm{~kg} / \mathrm{cm}^{3}$ for $15 \mathrm{~min}$.

The bacterial strains used in the experiment were sub-cultured into nutrient broth and incubated at $37{ }^{\circ} \mathrm{C}$ for $18 \mathrm{~h}$. The organisms were stored on sterile nutrient agar slants in McCatney bottles and sub-cultured at three months' interval to maintain them for further use.

The sensitivity testing of the compounds were determined using agar-well diffusion method [14], with some modification. The bacterial strains were first grown in nutrient broth for $18 \mathrm{~h}$ before use. About $0.2 \mathrm{~mL}$ of the standardized test isolates $(108 \mathrm{cfu} / \mathrm{mL}$ or $0.5 \mathrm{McFarland}$ standard) was then sub-cultured into Mueller-Hinton agar (LAB M). Wells were then bored into the agar medium using a sterile $6 \mathrm{~mm}$ cork borer. The wells were then filled up with prepared solutions of the complex. Care was taken not to allow solutions to spill on the surface of the medium. The plates were allowed to stand on the laboratory bench for about 1-2 $\mathrm{h}$ to allow for proper in flow of the solution into the medium before incubating the plate in an incubator at 37 ${ }^{\circ} \mathrm{C}$ for $24 \mathrm{~h}$. The plates were later observed for zones of inhibition, and the effects of the extract on bacterial strains were compared with that of standard antibiotic, ampicillin. 


\section{RESULTS AND DISCUSSION}

\section{Physicochemical parameters}

The precursor $\mathrm{MCl}_{2} \cdot \mathrm{XH}_{2} \mathrm{O}$ reacted with 2,2'-bipyridine (Bipy) and isoniazid (Is) in methanol to afford $\left[\mathrm{M}(\right.$ bipy $\left.)(\mathrm{Is})\left(\mathrm{H}_{2} \mathrm{O}\right) \mathrm{Cl}\right] \mathrm{Cl}$. The six complexes presented here are in octahedral molecular geometry surrounding the metal center according to magnetic moment measurement and spectroscopic studies. A representation of the synthetic route employed is shown in Scheme 1.The synthesis was carried out at room temperature under constant magnetic stirring. The physicochemical properties of the synthesized complexes are shown in Table 1. The mixed ligand complexes showed high melting points and a variety of colors ranging from greenish yellow to light pink except for the zinc complex which was whitish in color. The complexes displayed high melting points and that suggests high thermal stability.

The theoretical \%metal content in the mixed ligand complexes of isoniazid with $2,2^{\prime}-$ bipyridine showed a good correlation with the experimental values. All the complexes synthesized are soluble in water, while they show varying degrees of solubility in the five common solvents. The solubility of all the complexes in water suggests that they are ionic in nature. The molar conductivity of $\mathrm{Cu}(\mathrm{II}), \mathrm{Zn}(\mathrm{II}), \mathrm{Mn}$ (II) complexes are within the range of 92.00 to $130.00 \Omega^{-1} \mathrm{~cm}^{2} \mathrm{~mol}^{-1}$ depicting that they are $1: 1$ electrolytes while $\mathrm{Co}$ (II) complexes is a 1:2 electrolyte [15]. The molar conductivity of the Ni(II) complexes suggests that it is a nonelectrolyte.

Table 1. Physical properties and analytical data for compounds.

\begin{tabular}{|l|l|l|l|l|l|}
\hline Compound & $\begin{array}{l}\text { Formula } \\
(\mathrm{FW})\end{array}$ & Colour & $\begin{array}{l}\text { Melting } \\
\text { point } \\
\left({ }^{\circ} \mathrm{C}\right)\end{array}$ & $\begin{array}{l}\text { \% metal } \\
\text { found } \\
(\text { calc })\end{array}$ & $\begin{array}{l}\Lambda \mathrm{m} \\
\Omega^{-1} \mathrm{~cm}^{2} \mathrm{~mol}^{-1}\end{array}$ \\
\hline Isoniazid & $\mathrm{C}_{7} \mathrm{H}_{10} \mathrm{ON}_{2}(138.167)$ & White & 171 & - & - \\
\hline 2,2 -Bipyridine & $\mathrm{C}_{10} \mathrm{H}_{8} \mathrm{~N}_{2}(156.184)$ & White & $70-72$ & - & - \\
\hline$\left[\mathrm{Mn}(\mathrm{Is})(\mathrm{Bipy})\left(\mathrm{H}_{2} \mathrm{O}\right) \mathrm{Cl}\right] \mathrm{Cl}$ & $\begin{array}{l}\mathrm{MnC}_{17} \mathrm{H}_{20} \mathrm{ON}_{4} \mathrm{O}_{2} \mathrm{Cl}_{2} \\
(438.210)\end{array}$ & Yellow & $>350$ & $\begin{array}{l}12.60 \\
(12.54)\end{array}$ & 133.90 \\
\hline$\left[\mathrm{Co}(\mathrm{Is})(\mathrm{Bipy})_{2}\right] \mathrm{Cl}_{2} \cdot \mathrm{H}_{2} \mathrm{O}$ & $\begin{array}{l}\mathrm{CoC}_{27} \mathrm{H}_{26} \mathrm{~N}_{6} \mathrm{OCl}_{2} \\
(580.374)\end{array}$ & $\begin{array}{l}\text { Reddish } \\
\text { Brown }\end{array}$ & $226-234$ & $\begin{array}{l}9.94 \\
(9.85)\end{array}$ & 147.90 \\
\hline$\left[\mathrm{Ni}(\mathrm{Is})(\mathrm{Bipy}) \mathrm{Cl}_{2}\right] \cdot \mathrm{H}_{2} \mathrm{O}$ & $\begin{array}{l}\mathrm{NiC}_{17} \mathrm{H}_{20} \mathrm{ON}_{4} \mathrm{O}_{2} \mathrm{Cl}_{2} \\
(441.966)\end{array}$ & Green & $>350$ & $\begin{array}{l}13.52 \\
(13.28)\end{array}$ & 64.10 \\
\hline$\left[\mathrm{Cu}(\mathrm{Is})(\mathrm{Bipy})\left(\mathrm{H}_{2} \mathrm{O}\right) \mathrm{Cl}\right] \mathrm{Cl}$ & $\begin{array}{l}\mathrm{CuC}_{17} \mathrm{H}_{20} \mathrm{~N}_{4} \mathrm{O}_{2} \mathrm{Cl}_{2} \\
(446.818)\end{array}$ & $\begin{array}{l}\text { Greenish } \\
\text { Yellow }\end{array}$ & $298-301$ & $\begin{array}{l}14.50 \\
(14.22)\end{array}$ & 97.80 \\
\hline$\left[\mathrm{Zn}(\mathrm{Is})(\mathrm{Bipy})\left(\mathrm{H}_{2} \mathrm{O}\right) \mathrm{Cl}\right] \mathrm{Cl}$ & $\begin{array}{l}\mathrm{ZnC}_{17} \mathrm{H}_{20} \mathrm{~N}_{4} \mathrm{O}_{2} \mathrm{Cl}_{2} \\
(448.652)\end{array}$ & White & $>350$ & $\begin{array}{l}14.70 \\
(14.57)\end{array}$ & 92.00 \\
\hline
\end{tabular}

Infrared spectroscopy

Infrared spectra of the complexes are shown in Figure 1. Table 2 shows the significant absorption bands for the free ligands; isoniazid and 2,2-bipyridine and their $\mathrm{Cu}(\mathrm{II}), \mathrm{Mn}(\mathrm{II})$, $\mathrm{Co}(\mathrm{II}), \mathrm{Zn}(\mathrm{II})$, and $\mathrm{Ni}(\mathrm{II})$ complexes. Comparison of the infrared spectra of the free ligands with that of the metal complexes provided an evidence of coordination.

The bands due to the amino group in the isoniazid $\left(3340 \mathrm{~cm}^{-1}, 3214 \mathrm{~cm}^{-1}\right)$, carbonyl group $\left(1669 \mathrm{~cm}^{-1}\right)$ and N-H bend $\left(1493 \mathrm{~cm}^{-1}\right)$ are displayed. The data from the infrared spectra of the ligand and the complexes depicts that isoniazid acted as a bidentate ligand, which is in agreement with earlier reports [8]. In amides, coordination through the carbonyl oxygen results in a negative shift of the $\mathrm{C}=\mathrm{O}$ stretching frequency $[7,14]$. This was observed in the $\mathrm{Co}$ and $\mathrm{Ni}$ complexes which showed $\mathrm{C}=\mathrm{O}$ stretching frequencies at 1649 and $1651 \mathrm{~cm}^{-1}$ as against the $\mathrm{C}=\mathrm{O}$ stretching vibration. 
The disappearance of the $\mathrm{C}=\mathrm{O}$ band at $1669 \mathrm{~cm}^{-1}$ and subsequent appearance of the enolic $\mathrm{C}-\mathrm{O}$ stretching band at $1055,1059,1063 \mathrm{~cm}^{-1}$ for the $\mathrm{Mn}(\mathrm{II}), \mathrm{Cu}(\mathrm{II})$ and $\mathrm{Zn}$ (II), respectively, indicates enolization thus isoniazid coordinated to the metals via the enol oxygen [16]. There was an appearance of new bands at 627-637 and 415- $419 \mathrm{~cm}^{-1}$ which are due to M-O and M-N bands, respectively [10]. The appearance of a broad $\mathrm{O}-\mathrm{H}$ band at wave numbers from $3403 \mathrm{~cm}^{-1}$ to $3460 \mathrm{~cm}^{-1}$, depicts the presence of water molecule in the complexes.

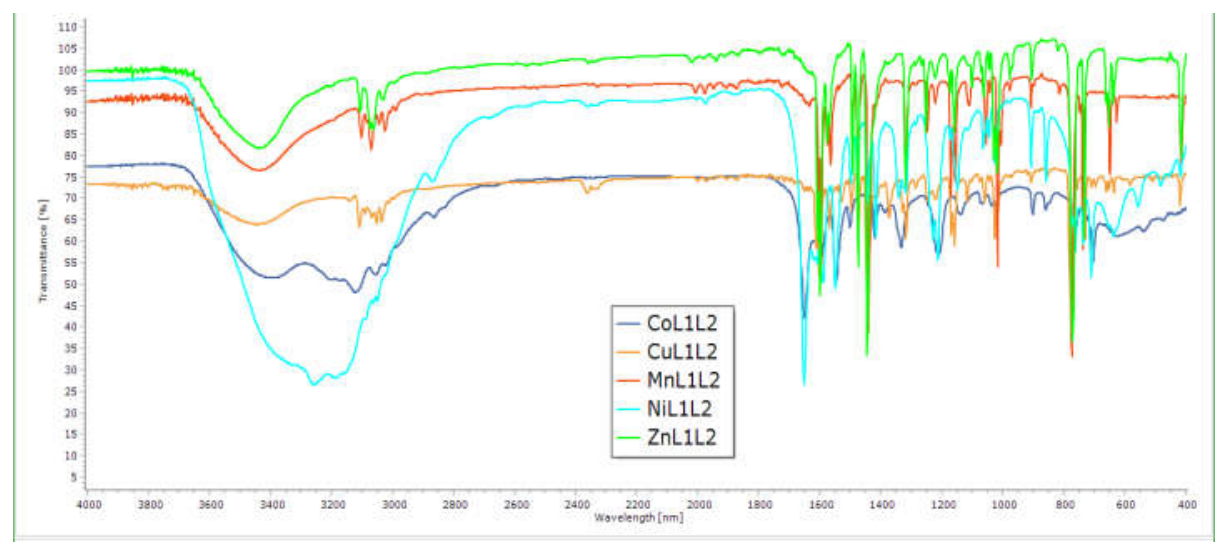

Figure 1. Infrared spectra of the complexes: $\mathrm{CoL}_{1} \mathrm{~L}_{2}, \mathrm{CuL}_{1} \mathrm{~L}_{2}, \mathrm{MnL}_{1} \mathrm{~L}_{2}, \mathrm{NiL}_{1} \mathrm{~L}_{2}, \mathrm{ZnL}_{1} \mathrm{~L}_{2}$.

Table 2. Some relevant infrared spectra data $\left(\mathrm{cm}^{-1}\right)$ of mixed ligand complexes of isoniazid.

\begin{tabular}{|c|c|c|c|c|c|c|c|c|}
\hline $\begin{array}{l}\text { Frequency/ } \\
\text { Compound }\end{array}$ & $v(\mathrm{OH})$ & $\begin{array}{l}v\left(\mathrm{NH}_{2}\right)_{(\mathrm{a})} \\
\mathrm{v}\left(\mathrm{NH}_{2}\right)(\mathrm{s})\end{array}$ & $v(\mathrm{NH})$ & $v(\mathrm{C}=\mathrm{O})$ & $v(\mathrm{C}-\mathrm{O})$ & $v(\mathrm{NH})_{(\mathrm{b})}$ & $v(\mathrm{M}-\mathrm{O})$ & $v(\mathrm{M}-\mathrm{N})$ \\
\hline Is & 3431 & $\begin{array}{l}3304 \\
3214\end{array}$ & 3113 & 1669 & & 1493 & - & - \\
\hline Bipy & - & - & - & - & & - & - & - \\
\hline $\mathrm{MnL}_{1} \mathrm{~L}_{2}$ & 3441 & - & 3100 & - & 1055 & 1490 & 627 & 415 \\
\hline $\mathrm{CoL}_{1} \mathrm{~L}_{2}$ & & $\begin{array}{l}3385 \\
3202\end{array}$ & 3121 & 1649 & & 1501 & 637 & 434 \\
\hline $\mathrm{NiL}_{1} \mathrm{~L}_{2}$ & & $\begin{array}{l}3258 \\
3187\end{array}$ & - & 1651 & & 1497 & 637 & 417 \\
\hline $\mathrm{CuL}_{1} \mathrm{~L}_{2}$ & 3447 & - & 3109 & - & 1059 & 1497 & 634 & 419 \\
\hline $\mathrm{ZnL}_{\mathrm{I}} \mathrm{L}_{2}$ & 3441 & - & 3063 & - & 1063 & 1490 & 652 & 415 \\
\hline
\end{tabular}

Electronic spectroscopy and magnetic susceptibility

Electronic spectral data measured in water as well as the magnetic measurements for the synthesized complexes are shown in Table 3. From the ultraviolet spectra, it can be observed that there are electronic transitions. These transitions are primarily intra-ligand in nature and since the ligands (isoniazid and 2,2-bipyridine) contains aromatic groups as well as atoms with nonbonding electrons, $\mathrm{n}-\pi^{*}$ and $\pi-\pi^{*}$ transitions are expected. However, the electronic transitions of the complexes exhibited a shift towards longer wavelength, with values that range from $220-321 \mathrm{~nm}$ which are also assigned to $\mathrm{n}-\pi^{*}$ and $\pi-\pi^{*}$ transitions [17]. This is an evidence of strong interaction between the ligand and the metallic ion. The extensive conjugation of the ligands gives rise to the several peaks as seen in ultraviolet spectra shown in Figure 2a. The visible spectra of the complexes are shown in Figure $2 b$. 
The visible spectrum of the Co(II) complex showed two bands at 509 and $664 \mathrm{~nm}$ which were assigned to ${ }^{4} \mathrm{~T}_{1 \mathrm{~g}} \rightarrow{ }^{4} \mathrm{~A}_{2 \mathrm{~g}}$ and ${ }^{4} \mathrm{~T}_{1 \mathrm{~g}} \rightarrow{ }^{4} \mathrm{~T}_{2 \mathrm{~g}}$. The visible spectrum of the $\mathrm{Cu}$ (II) complex displayed one band at $715 \mathrm{~nm}$ which was assigned to ${ }^{2} \mathrm{E}_{\mathrm{g}} \rightarrow{ }^{2} \mathrm{~T}_{2 \mathrm{~g}}$ transition that is expected for $\mathrm{Cu}(\mathrm{II})$ in an octahedral environment [18], while the nickel complex displayed two bands at 636 $\mathrm{nm}$, and $708 \mathrm{~nm}$, attributed which to ${ }^{3} \mathrm{~A}_{2} \mathrm{~g} \rightarrow{ }^{3} \mathrm{~T}_{1 \mathrm{~g}}(\mathrm{P}),{ }^{3} \mathrm{~A}_{2} \mathrm{~g} \rightarrow{ }^{3} \mathrm{~T}_{1 \mathrm{~g}}(\mathrm{~F})[19-20,22]$.

All the bands shown by the manganese complex in the visible region had very low intensities suggesting high spin octahedral geometry of the complex, since the transitions in a $\mathrm{d}^{5}$ $\left(\mathrm{Mn}^{2+}\right)$ high spin complex are all spin forbidden transitions, they give rise to very weak bands [19].

The zinc complex only displayed bands within $258-309 \mathrm{~nm}$ in the ultraviolet region, bands were absent in the visible region as zinc complex cannot produce d-d spectra [19]. The values reveals that all the complexes are paramagnetic, except the $\mathrm{Zn}(\mathrm{II})$ complex which is diamagnetic as expected for metals that possess a $\mathrm{d}^{10}$ configuration [14]. The magnetic moment value for $\mathrm{Cu}(\mathrm{II}), \mathrm{Ni}(\mathrm{II}), \mathrm{Co}(\mathrm{II})$, and $\mathrm{Mn}(\mathrm{II})$ which were $1.70,2.55,4.10$ and $6.8 \mathrm{BM}$ suggests an octahedral geometry for the complexes [19,23]. The predicted structures are shown in Figure 3.

Table 3. Electronic spectra and magnetic moments of mixed ligand complexes of isoniazid and 2,2bipyridine.

\begin{tabular}{|l|c|c|c|c|}
\hline Compound & $\begin{array}{c}\text { Intraligand } \\
\text { transitions }(\mathrm{nm})\end{array}$ & $\begin{array}{c}\text { Ligand field } \\
\text { transitions }\end{array}$ & Assignments & $\mu_{\mathrm{eff}}(\mathrm{BM})$ \\
\hline Isoniazid & 263 & - & $\mathrm{n} \rightarrow \pi^{*}$ & - \\
\hline 2,2'-Bipyridine & 240,306 & - & $\pi \rightarrow \pi^{*}, \mathrm{n} \rightarrow \pi^{*}$ & - \\
\hline$\left[\mathrm{Mn}(\mathrm{Is})(\mathrm{Bipy})\left(\mathrm{H}_{2} \mathrm{O}\right) \mathrm{Cl}\right] \mathrm{Cl}$ & 253,306 & $645(\mathrm{w})$ & $\begin{array}{c}\text { Forbidden } \\
\text { transitions }\end{array}$ & 6.80 \\
\hline$\left[\mathrm{Co}(\mathrm{Is})(\mathrm{Bipy})_{2}\right] \mathrm{Cl}_{2} \cdot \mathrm{H}_{2} \mathrm{O}$ & 255,274 & 508 & ${ }^{4} \mathrm{~T}_{1} \mathrm{~g} \rightarrow{ }^{4} \mathrm{~A}_{2} \mathrm{~g}$, & 4.10 \\
\hline$\left[\mathrm{Ni}(\mathrm{Is})(\mathrm{Bipy}) \mathrm{Cl}_{2}\right] \cdot \mathrm{H}_{2} \mathrm{O}$ & 298 & 668 & ${ }^{4} \mathrm{~T}_{1} \mathrm{~g} \rightarrow{ }^{4} \mathrm{~T}_{2} \mathrm{~g}$ & 2.55 \\
\hline$\left[\mathrm{Cu}(\mathrm{Is})(\mathrm{Bipy})\left(\mathrm{H}_{2} \mathrm{O}\right) \mathrm{Cl}\right] \mathrm{Cl}$ & $247,266,315,321$ & 715 & ${ }^{3} \mathrm{~A}_{2} \mathrm{~g} \rightarrow{ }^{3} \mathrm{~T}_{1} \mathrm{~g}(\mathrm{P})$, & 1.70 \\
\hline$\left[\mathrm{Zn}(\mathrm{Is})(\mathrm{Bipy})\left(\mathrm{H}_{2} \mathrm{O}\right) \mathrm{Cl}{ }_{2}\right]$ & 258,309 & - & ${ }^{2} \mathrm{E}_{\mathrm{g}} \rightarrow{ }^{2} \mathrm{~T}_{2 \mathrm{~g}}$ & 0.20 \\
\hline
\end{tabular}

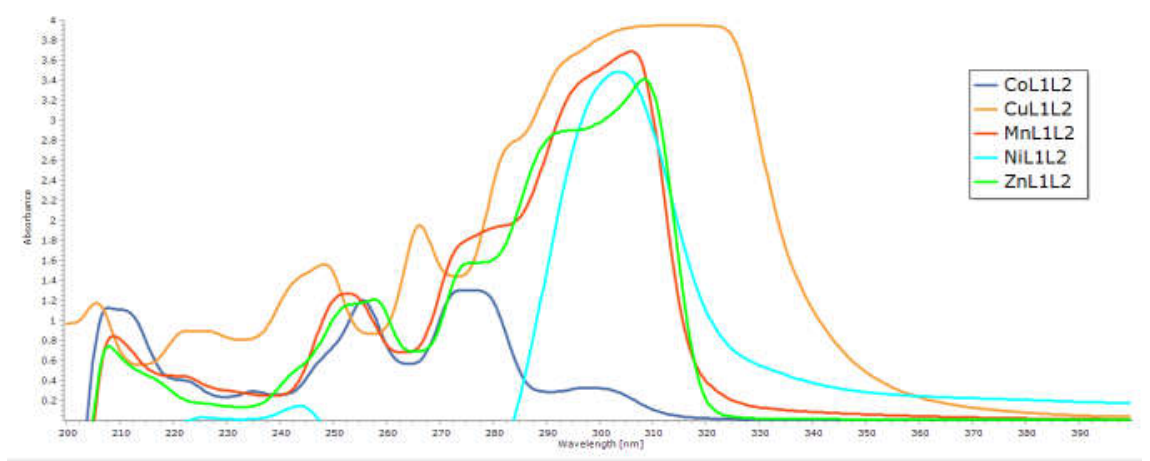

Figure 2a. UV spectra of the complexes: $\mathrm{CoL}_{1} \mathrm{~L}_{2}, \mathrm{CuL}_{1} \mathrm{~L}_{2}, \mathrm{MnL}_{1} \mathrm{~L}_{2}, \mathrm{NiL}_{1} \mathrm{~L}_{2}, \mathrm{ZnL}_{1} \mathrm{~L}_{2}$. 


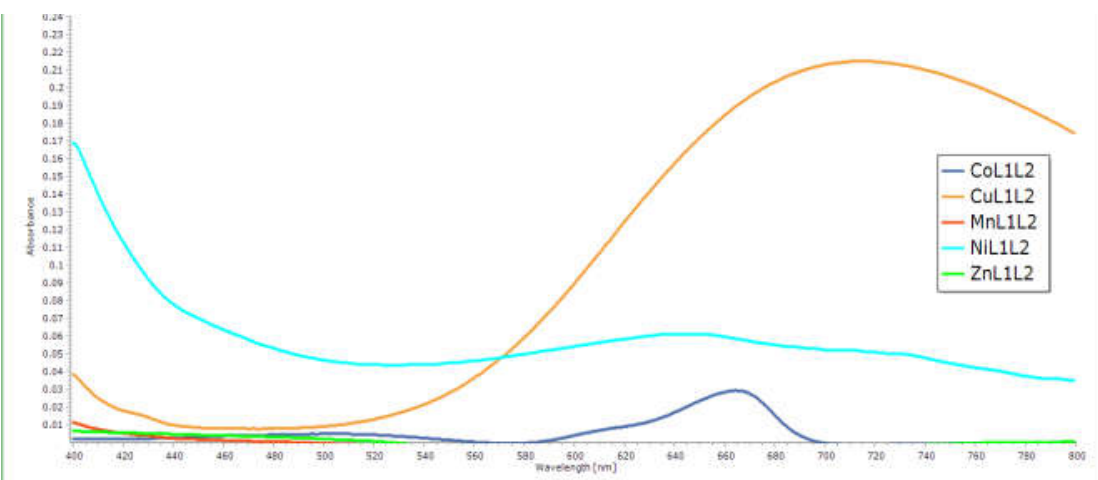

Figure 2b. Visible spectra of the complexes: $\mathrm{CoL}_{1} \mathrm{~L}_{2}, \mathrm{CuL}_{1} \mathrm{~L}_{2}, \mathrm{MnL}_{1} \mathrm{~L}_{2}, \mathrm{NiL}_{1} \mathrm{~L}_{2}, \mathrm{ZnL}_{1} \mathrm{~L}_{2}$.

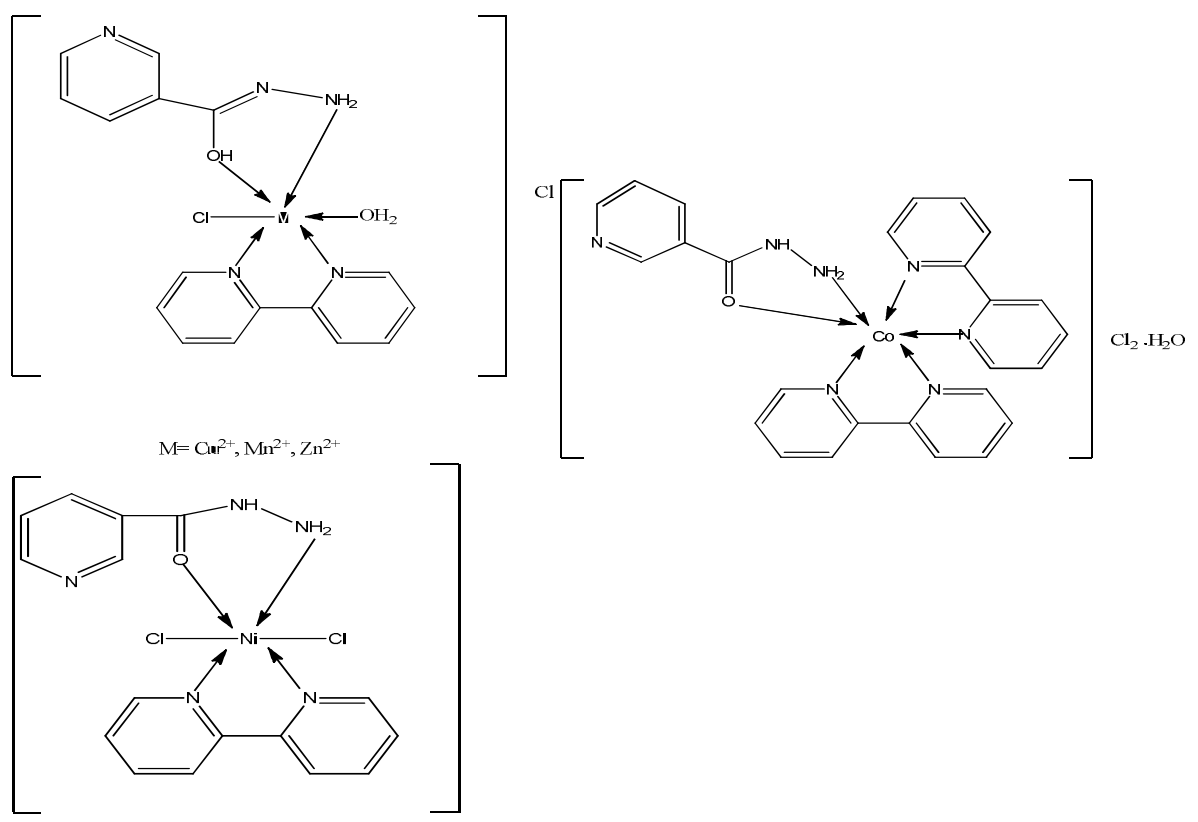

Figure 3. Predicted structures of complexes.

\section{Antibacterial activity}

The $\mathrm{Cu}(\mathrm{II}), \mathrm{Co}(\mathrm{II})$ mixed ligand complexes were tested against ten strains of bacteria consisting of five gram-negative and five gram-positive bacteria. The antibacterial activity was determined using $10 \mathrm{mg} / \mathrm{mL}$ of the synthesized complexes while $1 \mathrm{mg} / \mathrm{mL}$ ampicillin antibiotic was used as the standard. The zone of inhibition of the ligands and mixed ligand complexes are given in Table 4. The ligands and their mixed ligand complexes exhibited different ranges of antibacterial activity against the tested bacteria strains. The results showed that the ligands exhibited low antibacterial activity except for 2,2-bipyridine. The increased activity of the metal complexes may be attributed to an increase in their lipophilicity, which facilitates their 
absorption through the lipid bilayer of the microorganism [24, 25]. The metal complexes undertake their action on the micro-organisms through several ways, but particularly earlier reports on isoniazid have revealed that the complexes undergo dissociation once inside the cell thus releasing the cytotoxic ligands [26]. $\left[\mathrm{Cu}(\mathrm{Is})(\mathrm{Bipy})\left(\mathrm{H}_{2} \mathrm{O}\right) \mathrm{Cl}\right] \mathrm{Cl}$ displayed the highest activity on the microorganisms in term that are comparable to the standard (ampicillin), but it was found to have no activity on some of the microorganism.

Table 4. Zone of inhibition of the ligands and mixed ligand complexes.

\begin{tabular}{|l|c|c|c|c|c|c|c|c|c|c|}
\hline $\begin{array}{l}\text { Bacteria/ } \\
\text { Compound }\end{array}$ & $\begin{array}{c}E . \\
\text { coli }\end{array}$ & $\begin{array}{c}C . \\
\text { sporogenes }\end{array}$ & $\begin{array}{c}B . \\
\text { cereus }\end{array}$ & $\begin{array}{c}M . \\
\text { luteus }\end{array}$ & $\begin{array}{c}S . \\
\text { aureus }\end{array}$ & $\begin{array}{c}V . \\
\text { fuminisi }\end{array}$ & $\begin{array}{c}K . \\
\text { pnueomiae }\end{array}$ & $\begin{array}{c}P . \\
\text { fluoresens }\end{array}$ & $\begin{array}{c}P . \\
\text { ulgaris }\end{array}$ & $\begin{array}{c}P . \\
\text { aeriginus }\end{array}$ \\
\hline Is $\left(\mathrm{L}_{1}\right)$ & 0 & 0 & 0 & 10 & 0 & 0 & 12 & 0 & 0 & 0 \\
\hline Bipy $\left(\mathrm{L}_{2}\right)$ & 14 & 20 & 18 & 18 & 20 & 0 & 22 & 20 & 0 & 16 \\
\hline $\mathrm{CoL}_{1} \mathrm{~L}_{2}$ & 10 & 12 & 10 & 12 & 0 & 0 & 14 & 14 & 16 & 0 \\
\hline $\mathrm{CuL}_{1} \mathrm{~L}_{2}$ & 18 & 20 & 24 & 24 & 20 & 0 & 0 & 20 & 0 & 0 \\
\hline $\begin{array}{l}\text { Standard } \\
\text { ampicillin }\end{array}$ & 22 & 0 & 20 & 18 & 28 & 0 & 22 & 24 & 22 & 18 \\
\hline
\end{tabular}

\section{CONCLUSION}

In conclusion, the synthesis of $\mathrm{Mn}(\mathrm{II}), \mathrm{Co}(\mathrm{II}), \mathrm{Ni}(\mathrm{II}), \mathrm{Cu}(\mathrm{II})$ and $\mathrm{Zn}$ (II) complexes of isoniazid mixed with 2,2-bipyridine was carried out and characterized using UV spectroscopy, infrared spectroscopy, metal analysis, conductivity and magnetic measurements. The mixed ligand complexes displayed colours ranging from greenish yellow to light pink. The compounds were soluble in water, possessed high melting points which suggest thermal stability. Infrared spectra data revealed that the isoniazid and Bipyridine acted as bidentate ligands. The UV-Visible spectra in conjunction with the magnetic moments suggested an octahedral geometry for all the mixed ligand complexes. These observations were also supported by the conductivity measurement. The mixed ligand complexes showed moderate activity against the tested bacteria, with $\left[\mathrm{Cu}(\mathrm{Is})(\mathrm{Bipy})\left(\mathrm{H}_{2} \mathrm{O}\right) \mathrm{Cl}\right] \mathrm{Cl}$ having the highest antimicrobial activity which was comparable to that of the standard drug, ampicillin. This could be attributed to increased lipophilicity of the metal complexes.

\section{REFERENCES}

1. Davidson, L.A.; Takayama, K. Isoniazid inhibition of the synthesis of monounsaturated long-chain fatty acids in mycobacterium tuberculosis H37Ra. Antimicrob. Agents Chemother. 1979, 16, 104-105.

2. Centers for Disease Control and Prevention, $M M W R$ 2003, 52(RR-11), 1-72.

3. Smith, L.L.; Foell, T. Differentiation of $\Delta 4-3$-ketosteroids and $\Delta 1,4-3$-ketosteroids with isonicotinic acid hydrazide. Anal. Chem. 1959, 31, 102-105.

4. Nagano, K.; Kinoshita, H.; Hirakawa, A. Metal complexes of isonicotinoyl hydrazine and related compounds. IV. Composition formulae and infrared absorption spectra of metal complex crystals of isonicotinoyl hydrazine and related compounds. Chem. Pharm. Bull. 1964, 12, 1198-1206.

5. Nagano, K.; Kinoshita, H.; Hirakawa, A. Metal complexes of isonicotinoyl hydrazine and related compounds. infrared absorption spectra of isonicotinoyl hydrazine and related compounds. Chem. Pharm. Bull. 1964, 12, 1207-1217.

6. Bottari, B.; Maccari, R.; Monforte, F.; Ottana, R.; Rotondo, E.; Vigorita, M.G. Isoniazidrelated copper(II) and nickel(II) complexes with antimycobacterial in vitro activity. Bioorg. Med. Chem. Lett. 2000, 10, 657-660.

7. Pin, Y.; Xiaoping, Z. Synthesis and characterization of new chrominum(III), vanadium(IV), and titanium(III) complexes with biologically active isonicotinic acid hydrazide. J. Inorg. Biochem. 1989, 37, 61-68. 
8. Poggi, M.; Barroso, R.; Costa-Filho, A.J.; Barbosa de Barros, H.; Pavan, F.; Queico Leite, C.; Helvecia Torre, M. New isoniazid complexes, promising agents against Mycobacterium tuberculosis. J. Mexican Chem. Soc. 2013, 57, 198-204.

9. Sousa, E.H.S.; Basso, L.A.; Santos, D.S.; Diogenes, I.C.N.; Longhinotti, E.; De Franca Lopes, L.G.; De Sousa Moreira, I. Isoniazid metal complex reactivity and insights for a novel anti-tuberculosis drug design. J. Biol. Inorg. Chem. 2012, 17, 275-283.

10. Chaston, T.B.; Richardson, D.R. Interactions of the pyridine-2-carboxaldehyde isonicotinoyl hydrazone class of chelators with iron and DNA: Implications for toxicity in the treatment of iron overload disease. J. Biol. Inorg. Chem. 2003, 8, 427-438.

11. Koksharova, T.V.; Mandzii, T.V.; Stoyanova, I.V. Coordination compounds of cobalt(II), nickel(II), and zinc(II) valerates and benzoates with isonicotinic acid hydrazide. Russ. $J$. Gen. Chem. 2015, 85, 1896-1901.

12. Tyagi, D.K.; Kuma, K. Mixed ligand copper(II) complex with isoniazid and pyrazinamide. .J. Appl. Chem. 2014, 7, 13-16.

13. Bamigboye, M.O.; Obaleye, J.A.; Lawal, M.; Aluko, O.M. Synthesis, characterization and antimicrobial study of mixed isoniazid-trimethoprim metal drug complexes. Chem. Mater. Res. 2012, 2, 1-7.

14. Mbata, L.U.; Debiao, A.; Saikia, A. Antibacterial activity of the crude extract of Chinese green tea (Camellia sinensis) on Listeria monocytogenes. Afr. J. Biotechnol. 2008, 7, 15711573.

15. Geary, W.J. The use of conductivity measurements in organic solvents for the characterisation of coordination compounds. Coord. Chem. Rev. 1971, 7, 81-122.

16. Ramadevi, P.; Singh, R; Prajapati, A.; Gupta, S.; Chakraborty, D. Cu(II) complexes of isoniazid Schiff bases: DNA/BSA binding and cytotoxicity studies on A549 cell line. Adv. Chem. 2014, 2, 1-14.

17. Tavman, A.; Hacioglu, M.; Gurbuz, D.; Cinarli, A.; Oksuzomer, M.F.; Tan, A.B. Spectral characterization and antimicrobial activity of some transition metal complexes of 2-(5-nitro1H-benzimidazol-2-yl)-4-bromophenol. Bull. Chem. Soc. Ethiop. 2019, 33, 451-466.

18. Kriza, A.; Ababei, V.L.; Cioatera, N.; Rau, I.; Stanica, N. Synthesis and structural studies of complexes of $\mathrm{Cu}, \mathrm{Co}, \mathrm{Ni}$ and $\mathrm{Zn}$ with isonicotinic acid hydrazide and isonicotinic acid (1naphthylmethylene) hydrazide. J. Serb. Chem. Soc. 2010, 75, 229-242.

19. Lee, J.D. Concise Inorganic Chemistry, Blackwell Science Ltd: Oxford; 2013; pp 938-971.

20. Sacconi, L.; Bertini, L.; Mani, F. Metal complexes of N,N,N',N'-tetramethyldiamines. Nickel(II) and cobalt(II) complexes. Inorg. Chem. 1967, 6, 262-267.

21. Paboudam, A.G.; Gerard, C.; Mohamadous, A.; Agwara, M.O.; Conde, M.A.; Ndifon, P.T. Solution studies on $\mathrm{Co}(\mathrm{II}), \mathrm{Ni}(\mathrm{II}), \mathrm{Cu}(\mathrm{II})$, and $\mathrm{Zn}(\mathrm{II})$ complexes of hexamethylenetetramine in aqueous and non-aqueous solvents. Int. J. Inorg. Chem. 2014, 397132, 1-9.

22. Gaber, B.P.; Miskowski, V.; Spiro, T G. Resonance Raman scattering from iron(III)- and copper(II)-transferrin and an iron(III) model compound. Spectroscopic interpretation of the transferrin binding site. J. Am. Chem. Soc. 1974, 96, 6868-6873.

23. Cotton, F.A..; Wilkinson, G.; Murillo, C.A.; Boachman, M. Advanced Inorganic Chemistry, 6th ed., Wiley: New York; 2003; pp 761-875.

24. Ali, I.; Wani, W.A..; Khan, A.; Haque, A.; Ahmad, A.; Saleem, K.; Manzoor, N. Synthesis and synergistic antifungal activities of a pyrazoline based ligand and its copper(II) and nickel(II) complexes with conventional antifungals. Microbial. Pathogenesis 2012, 53, 6673.

25. Mainsah, E.N.; Ndifon, P.T.; Nfor, E.N.; Njapba, J.N. Synthesis, characterization and antibacterial properties of some transition metalcomplexes of (1H-pyrrol-2-yl)-isonicotinoyl hydrazone. Bull. Chem. Soc. Ethiop. 2013, 27, 395-404.

26. Farrell, N. Metal complexes as drugs and chemotherapeutic agents. Comprehensive Coordination Chemistry II 2003, 9, 809-840. 